\title{
PENGEMBANGAN MEDIA PEMBELAJARAN POWER POINT INTERAKTIF MELALUI PENDEKATAN SAINTIFIK UNTUK PEMBELAJARAN TEMATIK INTEGRATIF SISWA KELAS 2 SDN BERGAS KIDUL 03 KABUPATEN SEMARANG
}

\author{
Maria Resti Andriani \\ maria_resti_andriani@gmail.com \\ Wahyudi \\ wahyudi@staff.uksw.edu \\ Program Studi Pendidikan Guru Sekolah Dasar - FKIP \\ Universitas Kristen Satya Wacana Salatiga
}

\begin{abstract}
ABSTRAK
Penelitian ini adalah penelitian pengembangan yang bertujuan untuk mengembangkan media pembelajaran powerpoint interaktif melalui pendekatan saintifik untuk pembelajaran tematik intgratif siswa kelas 2 Sekolah Dasar. Model pengembangan yang digunakan untuk membuat media adalah model pengembangan ASSURE yang terdiri dari enam tahapan, yaitu: (1) analyze learners, (2) state objectives, (3) select method, media or materials, (4) Utilize media and materials, (5) require learner's participation,(6) evaluate and revise. Berdasarkan hasil uji pakar/ahli diperoleh hasil penilaian terhadap aspek media dengan skor rata-rata 3,81 dengan presentase $76,2 \%$ dengan kategori baik. Dan hasil penilaian pada aspek materi dengan skor rata-rata 48 dengan presentase $96 \%$, termasuk dalam kategori sangat baik. Serta hasil penelitian aspek pembelajaran diperoleh skor rata-rata 46 dengan persentase $92 \%$ dan termasuk dalam kategori sangat baik pula. Secara keseluruhan berdasarkan aspek materi, aspek media, dan aspek pembelajaran media pembelajaran powerpoint interaktif melalui pendekatan saintifik untuk pembelajaran tematik integratif siswa kelas 2 Sekolah Dasar dikatakan valid. Keefektifan media ditunjukkan dengan peningkatan rata-rata skor hasil belajar siswa sebesar 80,34 dengan presentase ketuntasan hasil belajar siswa mencapai $100 \%$.
\end{abstract}

Kata kunci: Pengembangan Media Pembelajaran Power Point Interaktif, saintifik, Tematik Integratif.

\section{PENDAHULUAN}

Kurikulum pendidikan di Indonesia selalu berubah dan berkembang sesuai zaman. Dalam penerapan kurikulum 2013 masih terdapat beberapa kekurangan dan perbedaan dari kurikulum sebelumnya. Salah satu kekurangannya adalah belum adanya media pembelajaran yang mendukung proses pembelajaran tematik 
Pengembangan Media Pembelajaran Power Point Interaktif Melalui Pendekatan Saintifik Untuk Pembelajaran Tematik Integratif Siswa Kelas 2 SDN Bergas Kidul 03 Kabupaten Semarang

(Maria Resti Andriani \& Wahyudi)

integratif dan sesuai dengan karakteristik siswa. Dengan adanya kekurangankekurangan tersebut diharapkan guru yang profesional mampu mengembangkan dan memanfaatkan media pembelajaran yang baik dan sesuai dengan kebutuhan siswa, tidak hanya asal mengambil materi dari internet. Seorang pengajar harus mampu mengkolaborasikan kemampuan merancang dan mengajar (padagogik), penguasaan konten (materi) dengan teknologi sehingga tercipta pembelajaran yang menarik dan menyenangkan yang mampu melayani siswa di era digital saat ini. Seiring dengan perkembangan teknologi, diperlukan pula kemampuan khusus yaitu pemanfaatan teknologi oleh guru (pengajar) dalam proses pembelajaran (technological).

Kemajuan teknologi yang menghampiri dunia pendidikan khususnya dalam hal pemanfaatan komputer dan internet sebagai media dan sumber belajar harus disikapi secara cepat oleh seorang pengajar atau guru sehingga kemajuan teknologi bisa termanfaat dengan baik untuk membantu proses pembelajaran di kelas. Pemanfaatan program aplikasi powerpoint sebagai media pembelajaran juga belum maksimal, suasana belajar, dan penyampaian materi banyak terpaku pada buku dan terkesan monoton atau kurang menarik perhatian siswa. Guru jarang sekali memanfaatkan atau membuat sendiri materi presentasi dengan bantuan powerpoint. Terkadang guru hanya mengunduh materi slide powerpoint yang mudah didapatkan di internet. Banyaknya materi dengan powerpoint di internet yang kurang sesuai dengan karakteristik siswa belum dilengkapi dengan soal-soal latihan atau permainan (game) interaktif yang memudahkan siswa lebih tertarik untuk belajarserta mampu mengerti dan menyerap pengetahuan dengan maksimal.

Melihat adanya beberapa permasalahan diatas, perlu adanya pengembangan media pembelajaran demi menunjang proses keberhasilan kurikulum 2013. Pengembangan dan pemanfaatan media pembelajaran interaktif, menjadi tantangan tersendiri bagi penulis untuk mengembangkan media pembelajaran yang mampu menyajikan materi dan dilengkapi dengan evaluasi atau soal-soal latihan dengan bantuan microsoft powerpoint yang efektif diterapkan pada siswa Sekolah Dasar.

\section{KAJIAN TEORI}

\section{Media Pembelajaran}

Kamus Besar Bahasa Indonesia, mengartikan media sebagai alat komunikasi dan informasi. Media berasal dari kata "medius" yang artinya tengah, perantara atau pengantar. Menurut Heinich dalam Rusman (2012:159) media merupakan wahana penyalur informasi belajar atau penyalur pesan. Media merupakan salah satu alat komunikasi dalam menyampaikan pesan tentunya sangat bermanfaat jika diimplementasikan ke dalam proses pembelajaran, media yang digunakan dalam proses pembelajaran disebut dengan media pembelajaran 
(Rusman, 2012:160). Gagne (1970) juga mengemukakan media adalah berbagai jenis komponen dalam lingkungan siswa yang dapat merangsangnya untuk belajar.

Berdasarkan beberapa pendapat tersebut media pembelajaran adalah media yang digunakan untuk mendukung proses pembelajaran di kelas dan membantu menumbuhkan motivasi belajar siswa.

\section{Microsoft PowerPoint}

Microsoft powerpoint merupakan aplikasi presentasi dalam komputer yang penggunaannya mudah, karena program powerpoint ini dapat diintegrasikan dengan microsoft lainnya seperti word, excel, access dan sebagainya (Susilana, 2007 : 99 ). Powerpoint juga merupakan salah satu program di bawah microsoft office program komputer dan tampilan ke layar dengan menggunakan bantuan LCD proyektor (Sanaky, 2009).

Pembelajaran menggunakan media powerpoint ini dirancang untuk pembelajaran yang interaktif, dimana dalam media presentasi powerpoint dirancang dan dilengkapi dengan alat pengontrol yang dapat dioperasikan oleh pengguna sehingga pengguna dapat memilih apa yang dikehendaki untuk petunjuk penggunaan, materi, dan soal latihan.

\section{Pendekatan Saintifik}

Menurut Permendikbud tentang Pedoman Umum Pembelajaran terdapat prinsip kerja yang menggunakan pendekatan saintifik, metode yang digunakan sesuai dengan karakteristik peserta didik dan mata pelajaran, yang meliputi aspek mengamati, menanya, menalar, mengumpulkan informasi dan mengkomunikasikan.

Menurut Daryanto (2014: 51) pembelajaran saintifik adalah proses pembelajaran yang dirancang sedemikian rupa agar peserta didik secara aktif mengkonstruksi konsep, hukum atau prinsip melalui tahap-tahap mengamati (untuk mengidentifikasi atau menemukan masalah), merumuskan masalah, mengajukan atau merumuskan hipotesis, mengumpulkan data dengan berbagai teknik, menganalisis data, menarik kesimpulan, dan mengomunikasikan konsep, hukum atau prinsip yang "ditemukan".

\section{Tematik Integratif}

Model pembelajaran tematik integratif dianggap sebagai salah satu model pembelajaran yang efektif. Pernyataan tersebut sesuai dengan Kementerian Pendidikan dan Kebudayaan (2014: 15) yang mengatakan bahwa tematik integratif diyakini sebagai salah satu model pembelajaran yang efektif karena mampu mewadahi dan menyentuh secara terpadu dimensi emosi, fisik, dan akademik siswa di dalam kelas atau di lingkungan sekolah. 
Pengembangan Media Pembelajaran Power Point Interaktif Melalui Pendekatan Saintifik Untuk Pembelajaran Tematik Integratif Siswa Kelas 2 SDN Bergas Kidul 03 Kabupaten Semarang

(Maria Resti Andriani \& Wahyudi)

Sedangkan pengertian mengenai tematik integratif dikemukakan oleh Yani (2014: 114) "pembelajaran tematik integratif adalah pembelajaran yang tidak menggunakan 'nama-nama disiplin ilmu' sebagai nama mata pelajaran tetapi menggunakan tema-tema tertentu. Tema tersebut mengikat beberapa pokok bahasan dari sejumlah mata pelajaran yang berbeda".

Dari pendapat diatas dapat disimpulkan bahwa pembelajaran tematik integratif adalah adanya penggabungan dari beberapa mata pelajaran ke dalam satu tema. Sehingga pembelajaran tematik integratif dapat diartikan sebagai pembelajaran yang menggunakan tema sebagai pengait beberapa mata pelajaran.

\section{METODE PENELITIAN}

\section{Prosedur Pengembangan}

Pengembangan media pembelajaran ini dibuat berdasarkan model pengembangan ASSURE (lihat Gambar 1). Model pengembangan ASSURE terdiri dari enam komponen seperti rumusan kata itu sendiri, yaitu 1) analyze learners, 2) state objectives, 3) select method, media or materials, 4) Utilize media and materials, 5) require learner's participation, 6) evaluate and revise (Heinich, Robert, Michael Molenda, James D. Russell, Sharon E. Smaldino, 2005).

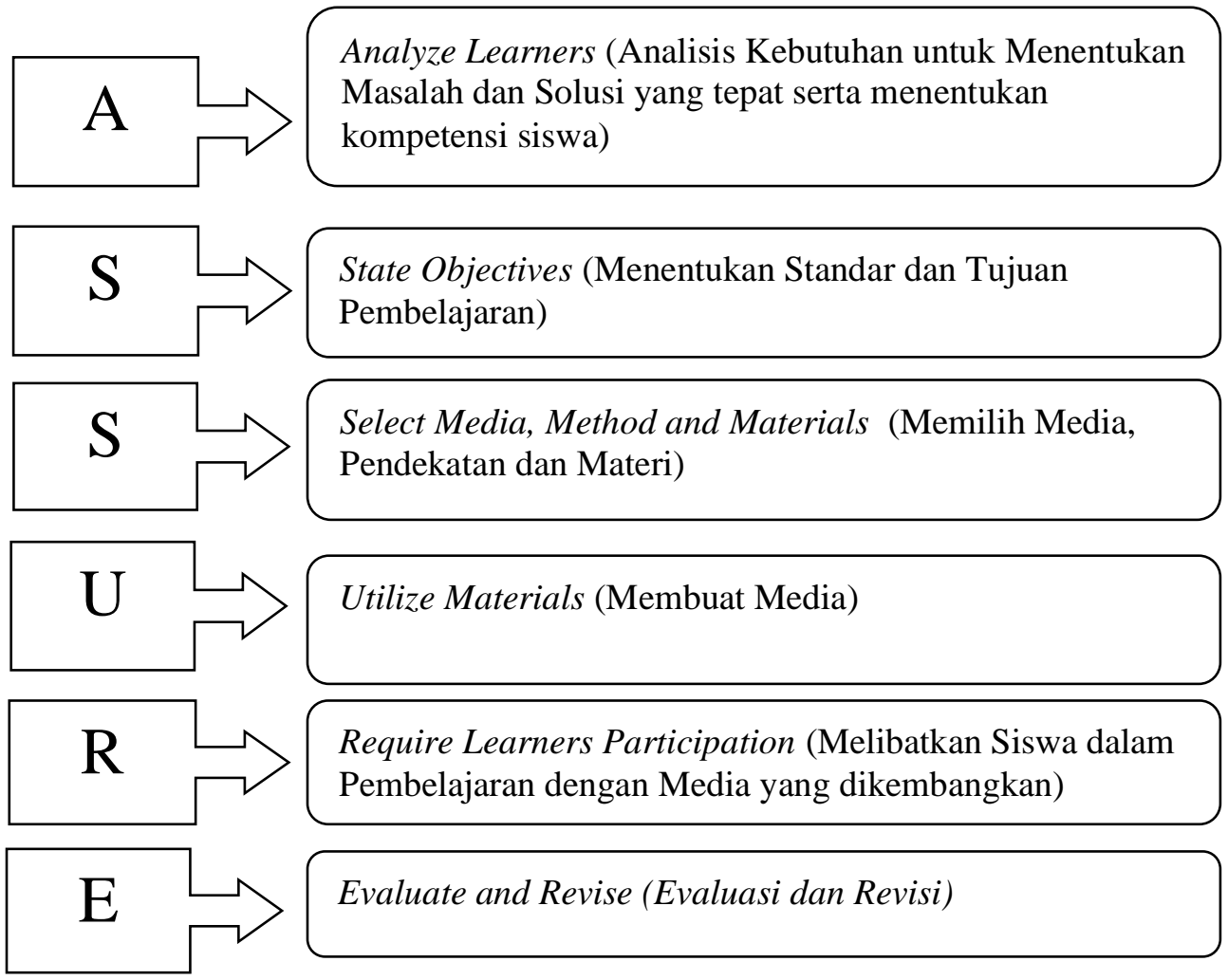

Gambar 1. Model Pengembangan ASSURE 


\section{Analyze Learners}

Analisis kebutuhan siswa merupakan langkah yang diperlukan untuk menentukan kemampuan-kemampuan atau kompetensi yang perlu dipelajari oleh siswa untuk meningkatkan efektivitas belajar. Analisis kebutuhan siswa dilakukan dengan melaksanakan observasi dan wawancara dengan kepala sekolah dan guru di SD yang sudah menerapkan kurikulum 2013. Selain itu, dilakukan pula analisis kinerja yang bertujuan untuk mengetahui dan mengklarifikasi beberapa persoalan mengenai penerapan kurikulum 2013, dan masalah dasar yang berkaitan dengan belum adanya media pembejaran yang mendukung bagi proses belajar siswa, sehinggga dibutuhkan solusi berupa suplemen/tambahan berupa media pembelajaran.

\section{State Objectives}

Pada tahap kedua peneliti merumuskan standar dan tujuan pembelajaran yang ingin dicapai. Satandar yang dibuat disesuaikan dengan standar yang ditetapkan pada kurikulum 2013. Merumuskan tujuan pembelajaran dapat menggunakan rumusan tujuan dengan format ABCD (Audiens, Behaviour, Conditions, and Degree).

\section{Select Method, Media or Materials}

Langkah ketiga dalam model pengembangan ini yaitu merancang dan memilih media pembelajaran yang sesuai dengan karakteristik siswa dan materi pembelajaran dalam kurikulum 2013. Selain itu, dilakukan pula penyusunan Rencana Pelaksanaan Pembelajran (RPP) untuk mendukung proses pembelajaran tematik integratif.

\section{Utilize Media and Materials}

Langkah keempat dalam model pengembangan ASSURE adalah pembuatan dan pengembangan media pembelajaran. Media dikembangkan melalui pendekatan saintifik untuk pembelajaran tematik integratif. Selain itu, media pembelajaran dirancang secara menarik, bervariasi, komunikatif dan interaktif, serta dilengkapi pula dengan informasi berupa teks, cerita, gambar dan video yang dikemas dalam bentuk CD. Media yang dikembangkan nantinya akan diujicobakan ke Sekolah Dasar. Namun sebelum diujicobakan ke SD, terlebih dahulu dilakukan validasi oleh pakar/ahli untuk melihat kualitas dan kelayakan dari media yang dikembangkan, serta mendapatkan masukan untuk merevisi media pembelajaran tersebut.

\section{Require Learner Participation}

Langkah selanjutnya adalah uji coba produk yang melibatkan siswa dalam pembelajaran. Sebelum dilakukan uji coba, siswa diberikan soal tes sebelum 
Pengembangan Media Pembelajaran Power Point Interaktif Melalui Pendekatan Saintifik Untuk Pembelajaran Tematik Integratif Siswa Kelas 2 SDN Bergas Kidul 03 Kabupaten Semarang (Maria Resti Andriani \& Wahyudi)

penggunaan media yang berupa soal uraian singkat. Soal evaluasi sesudah penggunaan media dalam pembelajaran yang diambil dari materi yang sudah pernah diajarkan sebelumnya. Langkah selanjutnya adalah uji coba media pembelajaran pada subyek penelitian. Dalam uji coba ini, guru beserta siswa menilai kualitas dari media yang telah dikembangkan. Hasil ini dijadikan sebagai dasar untuk merevisi produk. Proses setelah melakukan uji coba media pembelajaran adalah mengevaluasi dan menguji pemahaman siswa tentang materi yang sudah diajarkan dengan memberikan soal evaluasi sesudah peenggunaan media dalam proses pembelajaran.

\section{Evaluate and Revise}

Pada langkah evaluasi ini bertujuan untuk menganalisis kelayakan dan efektivitas media pembelajaran serta melakukan revisi produk berdasarkan evaluasi pada saat media diujicobakan. Kriteria valid dianalisis melalui hasil penilaian validator dengan lembar validasi pakar/ahli. Produk akhir dari pengembangan media merupakan hasil akhir revisi produk setelah diujicobakan pada siswa Sekolah Dasar.

\section{Teknik dan Instrumen Pengumpulan Data}

Teknik pengumpulan data yang digunakan dalam penelitian ini adalah penilaian pakar, angket, wawancara, observasi dan tes. Kevalidan media dapat dilihat dari hasil uji pakar media, materi dan pembelajaran dari ahli/pakarnya masing-masing. Keefektifan media dalam pembelajaran dapat diketahui melalui rata-rata hasil belajar siswa sebelum dan sesudah penggunaan media serta dilihat dari hasil lembar respon siswa.

\section{Analisis Data}

\section{Analisi Data Uji Pakar dan Lembar Respon Siswa}

Analisis pada data uji pakar media, materi dan pembelajaran dilakukan melalui dua cara, yaitu analisis kualitatif dan kuantitatif. Dalam menganalisis data dilakukan konversi skor kuantitatif ke dalam data kualitatif. Konversi skor tersebut dilakukan pada data skala 5 yang berupa lembar uji pakar media, materi dan pembelajaran berdasarkan skala Likert dengan skor penilaian mulai dari 1 sampai 5 (Suharsimi Arikunto, 2003). Pedoman konversi data kuantitatif ke dalam data kualitatif skala 5 dapat dilihat pada Tabel 11. 
Tabel 11

Pedoman Konversi Skor Kuantitatif Skala 5 ke dalam Data Kualitatif

$$
\begin{array}{ll}
x>4,01 & \text { Sangat Baik } \\
3,34<x \leq 4,01 & \text { Baik } \\
2,66<x \leq 3,34 & \text { Cukup } \\
1,99<x \leq 2,66 & \text { Kurang } \\
x<1,99 & \text { Sangat Kurang }
\end{array}
$$

\section{Keterangan:}

Mean $=$ rerata ideal

$=1 / 2($ skor maksimal ideal + skor minimal ideal $)$

$=1 / 2(5+1)$

$=1 / 2(6)$

$=3$

$S D \quad=$ Standar deviasi ideal

$=1 / 6($ skor maksimal ideal - skor minimal ideal $)$

$=1 / 6(5-1)$

$=1 / 6(4)$

$=2 / 3$

$x \quad=$ skor rerata data empiris

Sedangkan untuk lembar respon siswa dianalisis menggunakan kuesioner pengukuran skala Guttman. Skala Guttman sangat baik untuk menyakinkan peneliti tentang kesatuan dimensi dan sikap atau sifat yang diteliti, yang sering disebut dengan atribut universal (Usman Rianse dan Abdi, 2011: 155). Skala Guttman ini dalam bentuk checklist untuk mendapatkan jawaban yang tegas mengenai data yang diperoleh. Penskoran dalam skala Guttman adalah sebagai berikut :

\section{Tabel 12}

\section{Skoring Skala Guttman}

\begin{tabular}{ll}
\hline Alternatif Jawaban & Skor Alternatif Jawaban \\
\hline Ya & 1 \\
Tidak & 0 \\
\hline
\end{tabular}


Pengembangan Media Pembelajaran Power Point Interaktif Melalui Pendekatan Saintifik Untuk Pembelajaran Tematik Integratif Siswa Kelas 2 SDN Bergas Kidul 03 Kabupaten Semarang

(Maria Resti Andriani \& Wahyudi)

\section{Analisis Data Validasi Soal}

Validasi soal dilakukan untuk mengetahui tingkat validitas setiap soal. Validasi soal dilaksanakan secara expert judgment. Untuk menguji validitas konstruksi, dapat digunakan pendapat dari ahli (expert judgment). Ahli diminta pendapatnya, dan memberi keputusan tentang instrumen yang telah disusun dapat digunakan tanpa perbaikan, ada perbaikan, dan mungkin ada perombakan total (Sugiyono, 2012: 125).

\section{Analisis Tingkat Kesukaran Butir Soal}

Soal yang baik adalah soal yang tidak terlalu mudah atau terlalu sukar. Soal yang terlalu mudah tidak merangsang peserta didik untuk mempertinggi usaha memecahkannya, sebaliknya soal yang terlalu sukar akan menyebabkan peserta didik menjadi putus asa dan tidak mempunyai semangat untuk mencoba lagi karena di luar jangkauannya.

\section{Analisis Data Keefektifan Media PowerPoint Interaktif}

\section{Hasil Belajar Siswa}

Keefektifan penggunaan media powerpoint interaktif dilihat dari skor ratarata hasil belajar siswa sebelum dan sesudah penggunakan media dalam proses belajar di kelas. Kriteria Ketuntasan Minimal (KKM) pembelajaran tematik kurikulum 2013 di SD yaitu 66. Jika hasil belajar siswa mencapai nilai KKM minimal 66, maka dapat disimpulkan bahwa media powerpoint interaktif yang dikembangkan efektif.

Tabel 4

\section{Pedoman Keefektifan Hasil Belajar Siswa}

\begin{tabular}{lll}
\hline No & \% Yang Berhasil & Efektifitas \\
\hline 1 & $0 \leq p<41$ & Sangat Rendah \\
2 & $41 \leq p<56$ & Rendah \\
3 & $56 \leq p<66$ & Cukup \\
4 & $66 \leq p<80$ & Tinggi \\
5 & $80 \leq p<100$ & Sangat Tinggi \\
\hline
\end{tabular}

Keterangan :

$P \quad=$ persentase ketuntasan siswa $=\frac{P_{a}}{P_{b}} \times 100$

$P_{a} \quad=$ jumlah siswa tuntas

$P_{b} \quad=$ jumlah siswa keseluruhan 
Analisis hasil belajar siswa dengan menggunkan media dilakukan untuk menentukan efektivitas pembuatan media powerpoint interaktif yang dihasilkan dengan membuat data hasil belajar siswa, kemudian mengkonversi data hasil belajar pada siswa yang memenuhi standar minimal KKM dengan presentase pada pedoman keefektifan hasil belajar menurut Proklamanto (2013) dalam Tabel 4.

Hasil belajar dikatakan efektif jika mencapai persentase ketuntasan tinggi, sedangkan dikatakan sangat efektif jika mencapai persentase ketuntasan sangat tinggi.

\section{Respon Siswa}

Keefektifan media pembelajaran powerpoint interaktif juga dapat dilihat dari hasil respon siswa. Hasil respon siswa dianalisis sesuai dari respon siswa setelah diberikan pembelajaran menggunakan media powerpoint interaktif.

\section{HASIL PENELITIAN DAN PEMBAHASAN}

Pengembangan media pembelajaran powerpoint interaktif melalui pendekatan saintifik untuk pembelajaran tematik intgratif yang dikembangkan melalui model pengembangan ASSURE yang terdiri dari enam tahapan, yaitu: (1) analyze learners, (2) state objectives, (3) select method, media or materials, (4) Utilize media and materials, (5) require learner's participation,(6) evaluate and revise. Sebelum diujicobakan, media pembelajaran powerpoint interaktif dievaluasi oleh pakar/ahli (aspek media, aspek materi dan aspek pembelajaran).

\section{Hasil Validasi Pakar/Ahli}

Pada tahap ini dilakukan validasi media pembelajaran powerpoint oleh pakar atau ahli. Sebelum melakukan proses validasi pakar/ahli. Penilaian validasi media dilihat dari aspek tampilan, isi media, bahasa dan kepraktisan dalam penggunaan. Lembar penilaian validasi ini terdiri dari 16 indikator. Selain validasi dari aspek media, dilakukan pula validasi dari aspek materi yang terdiri dari 10 indikator dan validasi pembelajaran yang terdiri dari 10 indikator. Validasi dilaksanakan dengan tujuan agar media yang telah dibuat mendapat masukan dari validator yang memang ahli dalam bidangnya dan sebagai bukti bahwa media tersebut sudah layak untuk digunakan dalam penelitian. Kritik dan saran yang diberikan validator menjadi landasan dalam revisi media pembelajaran yang dikembangkan.

Setelah divalidasi langkah selanjutnya adalah uji coba produk yang melibatkan siswa dalam pembelajaran. Media powerpoint interaktif dengan pendekatan saintifik ini diuji cobakan ke SDN Bergas Kidul 03, Kabupaten Semarang. Uji coba dilakukan pada sekolah yang dijadikan subyek penelitian yaitu di kelas 2 SDN Bergas Kidul 03, Kabupaten Semarang. Sebelum dilakukan uji coba, siswa diberikan soal berupa soal uraian singkat yang kemudian dilanjutkan 
Pengembangan Media Pembelajaran Power Point Interaktif Melalui Pendekatan Saintifik Untuk Pembelajaran Tematik Integratif Siswa Kelas 2 SDN Bergas Kidul 03 Kabupaten Semarang (Maria Resti Andriani \& Wahyudi)

dengan melakukan uji coba pada subyek penelitian. Proses setelah berakhir uji coba media powerpoint interaktif, siswa diberikan soal evaluasi. Kemudian dilakukan evaluasi dan revisi.

\section{Analisis Data Kevalidan}

Analisis data kevalidan dilakukan berdasarkan hasil penilaian validator menggunakan lembar instrumen penilaian validasi media. Analisis data kevalidan terdiri aspek materi, media, dan aspek pembelajaran. Berikut penjelasan pada masing-masing aspek.

1) Aspek Media

Lembar penilaian aspek materi terdiri dari 12 indikator. Berdasarkan penilaian validator pada aspek materi diperoleh skor rata-rata 3,81 dengan presentase 76,2\% dengan kategori baik.

2) Aspek Materi

Lembar penilaian aspek media terdiri dari 10 indikator. Berdasarkan penilaian validator pada aspek media diperoleh skor rata-rata 48 dengan presentase $96 \%$ dengan kategori sangat baik.

3) Aspek pembelajaran

Lembar penilaian aspek media terdiri dari 10 indikator. Berdasarkan penilaian validator pada aspek media diperoleh skor rata-rata 46 dengan presentase $92 \%$ dengan kategori sangat baik.

\section{Analisis data keefektifan}

Keefektifan media powerpoint interaktif ini dinilai berdasarkan hasil lembar respon siswa serta hasil belajar siswa dengan pembelajaran menggunkan media powerpoint interaktif. Berdasarkan hasil lembar respon siswa diperoleh hasil respon rata-rata 32 siswa adalah 9,03, maka media powerpoint interaktif pada tema 7 subtema 2 ini dapat menarik minat belajar siswa. Kategori dari hasil respon siswa adalah sangat senang. Siswa menyatakan bahwa sangat senang belajar dengan menggunakan media powerpoint interaktif.

\section{Pembahasan}

\section{Kevalidan Media PowerPoint Interaktif}

Media yang dikembangkan melalui 6 tahapan dalam model ASSURE ini telah disetujui oleh validator dan setelah memperoleh hasil akhir, media video ini diuji cobakan. Uji coba media ini diujicobakan di SDN Bergas Kidul 03 Kabupaten Semarang dengan jumlah 32 siswa. Media powerpoint pada pembelajaran tematik integratif ini digunakan oleh guru sebagai media pembelajaran yang dibuat dengan 
menarik untuk meningkatkan efektivitas belajar siswa. Media powerpoint ini dilengkapi dengan gambar, video, soal latihan dan diskusi, serta kegiatan pembelajaran yang sesuai dengan pendekatan saintifik.

Media ini dirancang secara menarik untuk memotivasi siswa dalam mengikuti pembelajaran. Penilaian dalam media powerpoint ini dibagi menjadi tiga aspek yaitu aspek materi, aspek media dan aspek pembelajaran. Dari proses penilaian diperoleh kritik dan saran yang membangun. Hasil penelitian digunakan sebagai landasan dalam revisi media agar menjadi lebih baik lagi. Revisi media powerpoint terkait dengan aspek media seperti perbaikan kata pada tampilan awal media, jenis huruf (font), penambahan soal evaluasi, dan mengganti format video. Kemudian media direvisi sesuai dengan saran validator untuk memperbaiki media pembelajaran powerpoint interaktif ini. Berdasarkan hasil revisi media diperoleh hasil penilaian terhadap aspek media dengan skor rata-rata 3,81 dengan presentase $76,2 \%$ dengan kategori baik. Dan hasil penilaian pada aspek materi dengan skor rata-rata 48 dengan presentase $96 \%$, termasuk dalam kategori sangat baik. Serta hasil penelitian aspek pembelajaran diperoleh skor rata-rata 46 dengan persentase 92\% dan termasuk dalam kategori sangat baik pula. Secara keseluruhan berdasarkan aspek materi, aspek media, dan aspek pembelajaran media pembelajaran powerpoint interaktif melalui pendekatan saintifik untuk pembelajaran tematik integratif siswa kelas 2 Sekolah Dasar dikatakan valid.

\section{Keefektifan Pembuatan Media Video Interaktif}

\section{a. Persentase Ketuntasan Hasil Belajar Siswa}

Persentase ketuntasan hasil belajar siswa sesudah penggunaan media powerpoint interaktif adalah $100 \%$ menunjukkan keefektifan hasil belajar yang sangat tinggi. Hasil belajar dari 32 siswa adalah tuntas. Jumlah ini meningkat dibandingkan pada saat melihat kondisi awal yaitu pada saat pemberian soal tanpa menggunakan media, dan hanya 23 siswa yang tuntas dari 32 siswa. Hal ini membuktikan bahwa pada saat kondisi awal kemudian diberikan pembelajaran menggunakan media powerpoint interaktif menjadikan peningkatan pada hasil belajar siswa. Pengaruh dari kondisi awal kemudian dilakukan pemberian soal setelah melaksanakan pembelajaran dengan menggunakan media powerpoint interaktif mengalami peningkatan.

Selain ketuntasan pada hasil belajar setelah menggunakan media powerpoint interaktif, keefektifan penggunaan media powerpoint interaktif juga dapat dilihat dari rata-rata hasil belajar siswa dari sebelum dan sesudah menggunakan media powerpoint interaktif. Pemberian soal kepada 32 siswa sebelum penggunaan media pembelajaran, mendapatkan hasil rata-rata 70,27. Sedangkan hasil rata-rata dari hasil belajar 32 siswa setelah penggunaan media 
Pengembangan Media Pembelajaran Power Point Interaktif Melalui Pendekatan Saintifik Untuk Pembelajaran Tematik Integratif Siswa Kelas 2 SDN Bergas Kidul 03 Kabupaten Semarang

(Maria Resti Andriani \& Wahyudi)

powerpoint interaktif adalah 80,34 . Berikut ini adalah hasil rata-rata sebelum dan sesudah penggunaan media pembelajaran powerpoint interaktif.

Tabel 5

Rata-rata Hasil Belajar Siswa

\begin{tabular}{|c|c|c|}
\hline Keterangan & $\begin{array}{c}\text { Sebelum Penggunaan } \\
\text { Media }\end{array}$ & $\begin{array}{c}\text { Sesudah Penggunaan } \\
\text { Media }\end{array}$ \\
\hline Rata-Rata & 70,27 & 80,34 \\
\hline $\begin{array}{c}\text { Rata-Rata } \\
\text { Peningkatan }\end{array}$ & 10,07 \\
\hline
\end{tabular}

Berdasarkan data diatas dapat diketahui bahwa rata-rata nilai sesudah penggunaan media, siswa yang pada saat menggunakan media pembelajaran powepoint interaktif sebagai suplemen belajar lebih tinggi dari pada siswa yang diberikan soal evaluasi tanpa menggunakan media. Rata-rata nilai hasil belajar sesudah penggunaan media adalah 80,34 dengan presentase hasil belajar siswa yang tuntas adalah $100 \%$, hal ini menunjukkan keefektifan dalam penggunaan media pembelajaran powepoint interaktif sangat tinggi. Kesimpulan yang dapat diambil dari data tersebut adalah bahwa media pembelajaran powepoint interaktif efektif untuk digunakan pada siswa kelas 2 SDN Bergas Kidul 03 Kabupaten Semarang.

\section{b. Hasil Analisis Respon Siswa}

Berdasarkan hasil analisis dari lembar respon siswa yang terdiri dari 10 indikator, mencapai rata-rata 9,03 dan tergolong dalam kriteria sangat senang. Secara keseluruhan dapat disimpulkan bahwa respon siswa terhadap media powerpoint interaktif ini sangat positif, dan media ini efektif diterapkan dalam proses uji coba pembelajaran tematik integratif siswa kelas 2 SDN Bergas Kidul 03 Kabupaten Semarang.

\section{Temuan Penelitian}

Berdasarkan observasi penelitian penggunaan media pembelajaran powepoint interaktif pada tema 7 subtema 2 kelas 2 SD yang telah dilakukan peneliti memperoleh beberapa hal yang dapat dijadikan temuan penelitian yaitu:

a. Media pembelajaran powepoint interaktif sangat efektif untuk digunakan sebagai bahan ajar dalam pembelajaran tematik integratif. Karena semua hal yang tidak dapat dijangkau atau sulit untuk disajikan secara nyata, dapat 
disajikan di dalam media pembelajaran powepoint interaktif yang berbentuk CD sehingga mudah untuk dibawa kemanapun,

b. Dengan adanya media pembelajaran powepoint interaktif, dapat mengontrol siswa mengikuti pembelajaran dengan baik. Siwa juga merasa senang dan dapat lebih fokus mengikuti pembelajaran.

c. Siswa termotivasi dan tertarik mengikuti pembelajaran dengan media pembelajaran powepoint interaktif karena media pembelajaran ini dilengkapi dengan gambar, video, dan latihan soal yang dirancang dengan menarik, sehingga siswa tidak jenuh selama proses pembelajaran berlangsung.

Masih terdapat kelemahan dari media powerpoint interaktif. Kelemahan yang terdapat dalam media presentasi powerpoint adalah media ini tidak serba cocok untuk semua jenis dan tujuan pembelajaran. Oleh sebab itu, guru sebainya memahami benar tentang karakteristik media presentasi ini. Kualitas gambar video tidak bisa bagus karena powerpoint tidak mampu menampung video dengan kapasitas besar. Selain itu juga dibutuhkan ketrampilan khusus umtuk dapat menuangkan ide atau pesan yang baik pada powerpoint untuk mudah dicerna oleh penerima pesan atau penggunanya. Perlu persiapan yang matang, bila menggunakan teknik-teknik penyajian animasi yang kompleks.

\section{SIMPULAN}

Berdasarkan hasil penelitian dan pembahasan yang telah diuraikan sebelumnya, maka diperoleh beberapa kesimpulan sebagai berikut:

1. Produk yang dihasilkan dalam penelitian berupa $\mathrm{CD}$ media powerpoint interaktif melalui pendekatan saintifik untuk pembelajaran tematik integratif siswa kelas 2 SDN Bergas Kidul 03 Kabupaten Semarang dikembangkan sesuai 6 tahapan dalam model pengembangan ASSURE telah mendapatkan validasi dari ahli yang berkompeten dibidangnya. Berdasarkan penilaian validator pada aspek media diperoleh skor rata-rata 3,81 dengan persentase $76,2 \%$ dengan kategori baik. Aspek materi memperoleh skor rata-rata 48 dengan persentase $96 \%$ dengan kategori sangat baik. Kemudian untuk penilaian dari aspek pembelajaran memperoleh skor rata-rata 46 dengan presentase $92 \%$ dengan kategori sangat baik. Kesimpulan yang dapat diambil dalam penelitian ini adalah media pembelajaran powerpoint interaktif yang dihasilkan valid.

2. Keefektifan media pembelajaran powerpoint interaktif melalui pendekatan saintifik untuk pembelajaran tematik integratif siswa kelas 2 SDN Bergas Kidul 03 Kabupaten Semarang, dapat dilihat berdasarkan:

a. Skor rata-rata hasil belajar siswa dalam persentase ketuntasan siswa pada pemberian soal sesudah penggunaan media $100 \%$ dan mengalami peningkatan dari pada persentase hasil belajar sebelum penggunaan media. 
Pengembangan Media Pembelajaran Power Point Interaktif Melalui Pendekatan Saintifik Untuk Pembelajaran Tematik Integratif Siswa Kelas 2 SDN Bergas Kidul 03 Kabupaten Semarang

(Maria Resti Andriani \& Wahyudi)

Rata-rata nilai dari sebelum penggunaan media dan rata-rata peningkatan siswa yang pada saat pembelajaran didampingi media powerpoint interaktif lebih tinggi dari siswa yang tidak didampingi dengan media powerpoint interaktif. Kesimpulan yang dapat diambil berdasarkan hasil tersebut adalah media powerpoint interaktif yang dihasilkan efektif diterapkan pada pembelajaran tematik integratif siswa kelas 2 SDN Bergas Kidul 03 Kabupaten Semarang.

b. Hasil analisis lembar respon siswa mendapat respon positif dari siswa. Lembar respon siswa yang terdiri dari 10 indikator, mencapai rata-rata 9,03. Jadi, dapat disimpulkan bahwa menurut siswa media pembelajaran powepoint interaktif membuat siswa sangat senang belajar. Siswa merasa senang dan termotivasi mengikuti pembelajaran tematik integratif. Media ini juga memiliki tampilan yang menarik, karena dilengkapi dengan gambar, video, cerita membuat siswa tidak bosan dalam belajar. Pembelajaran yang disajikan dalam media powerpoint juga memudahkan siswa untuk memahami materi pembelajaran tema 7 subtema 2. Media ini terbilang efektif diterapkan dalam proses uji coba pembelajaran tematik integratif siswa kelas 2 SDN Bergas Kidul 03 Kabupaten Semarang.

\section{DAFTAR PUSTAKA}

Daryanto. 2014. Pendekatan Pembelajaran Saintifik Kurkulum 2013. Yogyakarta: Gava Media

Gagne, Robert M and Leslie J Briggs. 1970. Principles of Instructional Design.Harcourt Brace Jovanivich College Publisher.San Diego

Heinich, R., Molenda, M., Russell, J., \& Smaldino, S. 2001. Instructional Media and Technologies for Learning, 7th Edition. Englewood Cliffs: Prentice Hall, Inc.

Kamus Besar Bahasa Indonesia, Edisi Keempat. 2008. Jakarta: Gramedia Pustaka Utama

Kementerian Pendidikan dan Kebudayaan Republik Indonesia. 2014. Kurikulum 2013

Rusman. 2012. Model-Model Pembelajaran: Mengembangkan Profesionalisme Guru. Depok : PT Rajagrafindo Persada

Sanaky. 2009. Media Pembelajaran. Yogyakarta: Safiria Insania Press

Sugiyono. 2010. Metode Penelitian Kuantitatif Kualitatif Dan R\&D. Bandung: Alfabeta 
Scholaria, Vol. 6, No. 1, Januari 2016: 143 - 158

Suharsimi Arikunto. 2003. Dasar-dasar evaluasi pendidikan (Edisi Revisi). Jakarta: PT Bumi Aksara.

Susilana, Rudi dan Cepi Riyana. 2007. Media Pembelajaran. Bandung: CV Wacana Prima

Trianto. 2010. Model Pembelajaran Terpadu. Jakarta: Bumi Aksara 